\title{
Impact of White Mold Incidence on Dry Bean Yield Under Nonirrigated Conditions
}

\author{
L. E. del Río, J. R. Venette, and H. A. Lamey, Department of Plant Pathology, North Dakota State University, Far- \\ go 58105
}

\begin{abstract}
del Río, L. E., Venette, J. R., and Lamey, H. A. 2004. Impact of white mold incidence on dry bean yield under nonirrigated conditions. Plant Dis. 88:1352-1356.

Studies on chemical control of white mold, conducted between 1994 and 2001 at several locations in North Dakota, resulted in diverse levels of white mold incidence and severity. Navy bean cultivars were evaluated in on-farm trials between 1994 and 1996, while pinto bean cultivars were used between 1997 and 2001. The relationship between yield and white mold incidence in these trials was examined using correlation and regression analysis. White mold incidence was correlated to severity using a second-degree polynomial equation $\left(R^{2}=0.90, P=0.0001\right)$ in pinto bean experiments. For every percent unit increase in white mold incidence, yield was reduced by $12 \mathrm{~kg} / \mathrm{ha}$ (range 7 to $19 \mathrm{~kg} / \mathrm{ha}$ ) in pinto bean and by $23 \mathrm{~kg} / \mathrm{ha}$ (range 19 to $26 \mathrm{~kg} / \mathrm{ha}$ ) in navy bean. In both instances, the coefficients of determination were significant $(P<0.04)$ for most locations or years, and ranged from 0.42 to 0.87 for pinto bean and from 0.98 to 0.99 for navy bean. Fungicide-protected plots had an average white mold incidence of 34 and $50 \%$ compared with 76 and $73 \%$ in nonprotected plots for pinto and navy bean, respectively. Fungicide applications increased yields by 33 and $26 \%(P \leq 0.05)$ for pinto and navy bean, respectively.
\end{abstract}

North Dakota is the number one producer of dry edible beans (Phaseolus vulgaris L.) in the United States, with an estimated production of $4.83 \times 10^{5}$ tons in 2002 valued at over $\$ 157$ million (11). Surveys conducted among dry bean producers in North Dakota and Minnesota in the past several years indicated that white mold, caused by the fungus Sclerotinia sclerotiorum (Lib.) de Bary, is the most important disease affecting dry bean production in the region (15-17).

White mold can be especially severe when wet and cool conditions are prevalent during the crop's early reproductive stages (1). Airborne ascospores, considered the primary source of inoculum (28), colonize senescent tissues, especially petals, and subsequently invade the main stem and branches of plants. Infected plants wither and die within several days after inoculation. Yield losses due to this disease in the past 10 years have been estimated at several million dollars. Characterization of the relationship between white mold and yield on dry bean is necessary not only to better estimate losses due to this disease, but also to help in the selection of control measures and determine when control is possible or cost

Corresponding author: L. del Río

E-mail: Luis.delRio-Mendoza@ndsu.nodak.edu

Accepted for publication 13 August 2004.

Publication no. D-2004-1015-01R

(C) 2004 The American Phytopathological Society had four replications. effective. This article presents one approach to address this issue.

\section{MATERIALS AND METHODS}

Field data were collected in eight replicated experiments conducted between 1997 and 2001 at the North Dakota State University Experimental Centers in Oakes and Carrington, and in on-farm trials con- ducted at five locations in Grand Forks County, ND between 1994 and 1996.

Replicated experiments. White moldsusceptible pinto bean cultivars were planted for all replicated experiments. 'Topaz' was planted in 1997 and 1998, 'Hatton' in 1999, and 'Buster' in 2000 and 2001. All pinto bean cultivars were planted at a density of $190,000 \mathrm{seed} / \mathrm{ha}$. Experimental plots consisted of four rows, each 6 $\mathrm{m}$ in length and spaced every $76 \mathrm{~cm}$. Treatments were replicated four times at each location using a randomized completeblock design. The herbicides trifluralin and metolachlor were applied prior to planting at a rate of 1.2 and 1.7 liters/ha, respectively, followed by postemergence application of bentazon at a rate of 2.3 liters/ha. Between 1997 and 2000, the experimental plots were exposed to ascospores produced in the fields. In 2001, a suspension of laboratory-produced ascospores $\left(10^{4}\right.$ ascospores $/ \mathrm{ml}$ ) was sprayed on each experimental plot at R1 stage, when there was at least one open flower on each plant (18). All experiments included positive and negative controls, treated with benomyl or thiophanate-methyl at 0.5 to $1.2 \mathrm{~kg}$ a.i./ha or untreated, respectively. Additional treat-

Table 1. Fungicide treatments applied to replicated experiments at two locations in North Dakota between 1997 and 2001

\begin{tabular}{lccccc}
\hline & \multicolumn{5}{c}{ Years $^{\mathbf{a}}$} \\
\cline { 2 - 6 } Fungicide treatments $^{\mathbf{b}}$ & $\mathbf{1 9 9 7}$ & $\mathbf{1 9 9 8}$ & $\mathbf{1 9 9 9}$ & $\mathbf{2 0 0 0}$ & $\mathbf{2 0 0 1}$ \\
\hline Untreated control & + & + & + & + & + \\
Calcium sulfate & + & + & + & + & - \\
Calcium sulfate + thiophanate-methyl & + & - & + & + & - \\
Calcium sulfate + benomyl & - & + & + & + & - \\
Calcium sulfide & - & + & - & - & - \\
Calcium sulfide + benomyl & - & + & - & - & - \\
Calcium nitrate & + & - & - & - & - \\
Calcium nitrate + thiophanate-methyl & + & - & - & - & - \\
Calcium chelate & + & - & - & - & - \\
Calcium chelate + thiophanate-methyl & + & - & - & - & - \\
Calcium chloride & - & + & - & + & + \\
Calcium chloride + thiophanate-methyl & - & - & - & + & + \\
Calcium chloride + benomyl & - & + & - & + & - \\
Crop Booster NutriCal & - & + & - & - & - \\
Crop Booster Super Cal & - & + & - & - & - \\
Calcium EDTA 3\% & - & + & - & - & - \\
Flo-Gyp & - & - & - & - & + \\
Thiophanate-methyl & + & - & + & + & + \\
Benomyl & - & + & + & + & -
\end{tabular}

${ }^{a}$ Compound evaluated (+) or not evaluated (-) that year. Experiments were conducted at single locations in 1997 and 1998, and at two locations from 1999 through 2001. Experiments at each location

b Rate of compounds as follow: calcium sulfate, 0.04 to $4.5 \mathrm{~kg} / \mathrm{ha}$; calcium chloride, 9.3 liters/ha; all other calcium compounds, 1.1 to $3.3 \mathrm{~kg} / \mathrm{ha}$; thiophanate-methyl, 0.4 to $1.2 \mathrm{~kg} / \mathrm{ha}$ a.i.; benomyl, 0.3 to $0.8 \mathrm{~kg} / \mathrm{ha}$ a.i. These compounds and fungicides were applied separately or in combination in several proportions for white mold control at flowering time (R1 stage). 
Table 2. Impact of fungicide application on white mold incidence and yield of pinto beans in replicated experiments between 1997 and 2001 at two North Dakota locations ${ }^{\mathrm{a}}$

\begin{tabular}{|c|c|c|c|c|c|c|c|c|}
\hline \multirow[b]{3}{*}{ Location } & \multirow[b]{3}{*}{ Year } & \multicolumn{5}{|c|}{ White mold incidence (\%) } & & \\
\hline & & \multicolumn{2}{|c|}{ Not protected } & \multicolumn{2}{|c|}{ Fungicide protected } & \multirow[b]{2}{*}{ Probability } & \multicolumn{2}{|c|}{ Yield increase } \\
\hline & & Mean & Range & Mean & Range & & Percent & Probability \\
\hline Carrington & 1997 & 97 & $95-100$ & 44 & $36-59$ & 0.0001 & 39 & 0.0001 \\
\hline Carrington & 1998 & 12 & $5-23$ & 6 & 0-9 & 0.2586 & 14 & 0.3600 \\
\hline Carrington & 1999A & 66 & $45-95$ & 10 & $5-15$ & 0.0019 & 58 & 0.0102 \\
\hline Carrington & 1999B & 80 & $50-100$ & 43 & $20-90$ & 0.1062 & 33 & 0.0019 \\
\hline Carrington & 2000 & 44 & $35-55$ & 5 & $0-15$ & 0.0004 & 3 & 0.6569 \\
\hline Oakes & 2000 & 74 & $65-90$ & 29 & $10-65$ & 0.0173 & 22 & 0.0195 \\
\hline Carrington & 2001 & 83 & $70-90$ & 58 & $45-65$ & 0.0082 & 14 & 0.0231 \\
\hline Oakes & 2001 & 91 & $80-100$ & 46 & $15-85$ & 0.0282 & 11 & 0.1925 \\
\hline
\end{tabular}

${ }^{a}$ Means based on four replications per experiment and year.

ments included mixtures of diverse calcium compounds (Table 1) with either one of these fungicides applied once or twice at flowering time. White mold incidence and severity were estimated simultaneously in the two central rows of each plot when the plants were at the R7 stage. At this stage, no more pods are formed in type I (determinate) bean and only a few flowers may still be produced on the vines of type III (indeterminate) bean (18). Ten plants in each of the two central rows of each plot were examined visually for disease incidence and severity. Disease incidence was calculated as the percentage of symptomatic plants. Severity ratings were estimated in the field by adopting a scale of 0 to 5 , where $0=0 \%, 1=5 \%, 2=15 \%$, $3=40 \%, 4=65 \%$, and $5=85 \%$ of the plant affected by the pathogen. Means for severity were calculated from plants showing white mold symptoms. Severity ratings later were transformed into percentages. At harvest time, a 3-m-long section was marked in the center two rows of each plot. All plants within the section were collected in burlap bags. Bags were stored in forcedair driers at $49^{\circ} \mathrm{C}$ for 2 to 5 days, and threshed using a Seedburo stationary belt thresher (Seedburo Equipment, Chicago, IL). Yields were estimated and expressed at $8 \%$ seed moisture content.

On-farm trials. All trials were conducted on navy bean cultivars. Commercial plantations of nonidentified navy cultivars

Table 3. Percent yield difference between nonprotected and fungicide-protected plots in on-farm trials with navy beans between 1994 and 1996 at four North Dakota locations

\begin{tabular}{lclcccc}
\hline & & & \multicolumn{3}{c}{ White mold incidence (\%) } & \\
\cline { 4 - 6 } Location & Year & Cultivar $^{\mathbf{a}}$ & Protected & Not protected & Probability $^{\mathbf{b}}$ & Yield reduction (\%) \\
\hline Northwood & 1994 & $\ldots$ & 69 & 92 & 0.05 & 45 \\
Hatton & 1995 & $\ldots$ & 9 & 45 & 0.05 & 21 \\
Cummings & 1996 & Envoy & 47 & 78 & 0.05 & 21 \\
Cummings & 1996 & Schooner & 13 & 32 & 0.05 & 24 \\
Buxton & 1996 & Norstar & 76 & 95 & 0.05 & 24 \\
Buxton & 1996 & Schooner & 58 & 73 & 0.05 & 21 \\
Buxton & 1996 & Upland & 77 & 95 & 0.05 & 26 \\
\hline
\end{tabular}

a ... Indicates navy bean cultivars not identified.

${ }^{\mathrm{b}}$ Probability based on Student $t$ test with 15 observations per location and (protected versus nonprotected) strips.

were used in 1994 and 1995, whereas cvs. Envoy, Schooner, and Norstar were used in 1996. Nonreplicated field strips, 1.3 to 3.1 ha in size, were established at several commercial bean fields in North Dakota between 1994 and 1996 to compare the impact of different spraying systems on white mold control. In 1994 and 1995, strips were established near Northwood and Hatton, respectively; whereas, in 1996, strips were established at Cummings, Mayville, and Buxton. At each location, one strip was left untreated (control) while the other was sprayed at the same growth stage as the replicated experiments, with either benomyl or thiophanate-methyl at 1.1 or $1.6 \mathrm{~kg}$ a.i./ha, respectively, using commercial ground sprayers or aerial applicators. The strips were managed in the same way as the rest of the commercial field. White mold incidence was estimated at the R7 stage following the procedure described for the replicated experiments. A total of 15 sampling sites, spaced every $40 \mathrm{~m}$, were made within each strip and the average incidence calculated. Strips were harvested using commercial combines. Yields were estimated in the field.

Data analysis. An analysis of variance using the General Linear Model procedure of SAS (SAS Institute, Cary, NC) was conducted to discriminate between yield of protected and unprotected plots in replicated experiments. Bartlett's test for homogeneity of variances also was conducted to evaluate the possibility of combining data from experiments con-

Table 4. Relationship between white mold incidence and dry bean yields in replicated field trials in North Dakota between 1997 and 2001

\begin{tabular}{|c|c|c|c|c|c|c|c|}
\hline Year & Location & Market class & Cultivar $^{\mathbf{a}}$ & Intercept & Slope & $R^{2}$ value & Probability \\
\hline \multicolumn{8}{|c|}{ On-farm trials } \\
\hline 1994 & Northwood & Navy & $\ldots$ & 3550 & -18.99 & 0.99 & 0.0003 \\
\hline 1995 & Hatton & Navy & $\ldots$ & 2739 & -7.46 & 0.25 & 0.2109 \\
\hline 1996 & Cummings & Navy & Envoy & 2390 & -15.40 & 0.78 & 0.1182 \\
\hline 1996 & Cummings & Navy & Schooner & 2246 & -26.44 & 0.98 & 0.0096 \\
\hline 1996 & Buxton & Navy & Norstar & 3545 & -22.38 & 0.76 & 0.1272 \\
\hline \multicolumn{8}{|c|}{ Replicated experiments } \\
\hline 1997 & Carrington & Pinto & Topaz & 4638 & -19.07 & 0.87 & 0.0002 \\
\hline 1998 & Carrington & Pinto & Topaz & 2786 & -6.72 & 0.06 & 0.4800 \\
\hline 1999 & Carrington A & Pinto & Hatton & 3160 & -14.23 & 0.70 & 0.0014 \\
\hline 1999 & Carrington B & Pinto & Hatton & 3337 & -11.46 & 0.55 & 0.0089 \\
\hline 2000 & Carrington & Pinto & Buster & 3054 & -5.68 & 0.24 & 0.1249 \\
\hline 2000 & Oakes & Pinto & Buster & 4123 & -7.04 & 0.42 & 0.0322 \\
\hline 2001 & Carrington & Pinto & Buster & 4278 & -10.57 & 0.53 & 0.0070 \\
\hline 2001 & Oakes & Pinto & Buster & 3725 & -10.99 & 0.43 & 0.0208 \\
\hline
\end{tabular}

a ... Indicates navy bean cultivars not identified. 

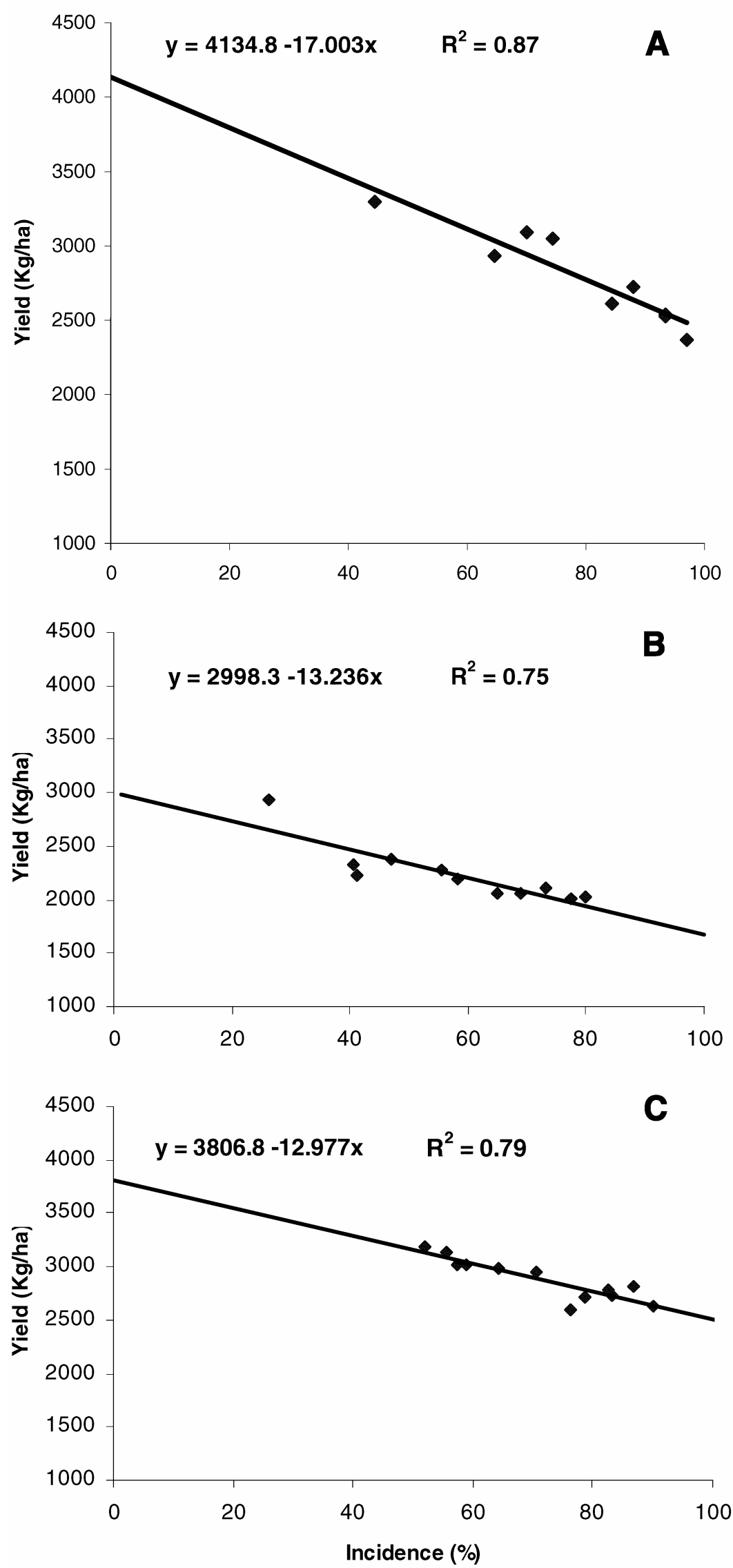

Fig. 1. Correlations between white mold incidence and dry bean yields from $\mathbf{A}$, a single location at Carrington in 1997, B, a combined analysis of two Carrington locations in 1999, and C, a combined analysis of two locations, Carrington and Oakes, in 2001. Each data point represents the average of four observations (1997), and eight observations (1999 and 2001). All coefficients of determination were significant at $P<0.001$. ducted in the same year. Data from onfarm trials was analyzed using a Student $t$ test where each sampling site was considered an observation. The association between yield and disease level generated by fungicide application in both replicated and on-farm trials was examined through regression and correlation analysis with the Correlation and Regression procedures of SAS.

\section{RESULTS}

The impact of fungicide applications on white mold incidence varied from year to year and location to location in both replicated and on-farm trials; in general, fungicide application reduced white mold incidence and increased yield significantly. The mean white mold incidence across experiments was $34 \%$ on fungicide-protected plots compared with $76 \%$ in nonprotected plots (Table 2). Fungicide-protected plots also had significantly higher yields at all sites and years, except at Carrington in 1998 and 2000 and at Oakes in 2001. Significant yield increments ranged from 14 to $58 \%$, with a mean of $33 \%$.

In on-farm trials, significant differences were detected for white mold incidence and yield between nonprotected and fungicide-protected strips at all sites and years (Table 3). White mold incidence for nonprotected strips ranged from 32 to $95 \%$, with an overall mean of $73 \%$, whereas the incidence in fungicide-protected strips ranged from 9 to $77 \%$, with an overall mean of $50 \%$. Yield in nonprotected strips ranged from 21 to $45 \%(P=0.05)$ less than that of fungicide-protected strips. The mean yield reduction across trials was $26 \%$.

White mold incidence was negatively correlated with dry bean yield in most of the replicated trials and in two of five onfarm trials (Table 4). Yield losses ranged from 7 to $19 \mathrm{~kg} / \mathrm{ha}$ for each percent unit increment in white mold incidence in replicated trials and from 19 to $29 \mathrm{~kg} / \mathrm{ha}$ in onfarm trials. Coefficients of determination $\left(R^{2}\right)$ that were significant $(P<0.05)$ ranged from 0.42 to 0.87 for replicated trials and 0.91 to 0.98 for on-farm trials. Data from locations in the year 2000 could not be pooled according to Bartlett's test for homogeneity of variances, but those from years 1999 and 2001 were pooled. The combined analysis for both 1999 and 2001 improved the coefficients of determination $\left(R^{2}\right)$ to 0.75 and 0.79 , respectively (Fig. 1). The average yield reductions per incidence unit for both years were 13.2 and 13.0, respectively. A nonlinear association, explained by a second-degree polynomial equation $\left(R^{2}=0.90, P=0.0001\right)$, was identified between disease incidence and disease severity assessments made on replicated trials (Fig. 2).

\section{DISCUSSION}

White mold is a difficult disease to manage with fungicide applications alone. 
Plant infection usually starts after ascospores released from apothecia have colonized senescent floral tissues (2). The disease progresses rapidly when cool and wet weather is present (29), and closed, dense canopies extend plant surface wetness for prolonged periods of time (4). The efficacy of fungicide applications to control this disease may be influenced by a number of factors, such as timing of fungicide application (22), fungicide penetration to lower parts of the canopy (22), presence of strains of the pathogen with enhanced tolerance for the fungicides applied $(9,23)$, and fungicide degradation by alkaline hydrolysis (6). Current recommendations in North Dakota suggest to spray when the crop is at full bloom using drop nozzles and high pressure (14). A second application 7 to 10 days later is recommended if conditions are favorable for disease development. However, the use of drop nozzles has been abandoned by many growers that plant bean cultivars in rows $55 \mathrm{~cm}$ apart because they get tangled with the crop canopy and break. And even though compounds like thiophanate methyl, the most popular fungicide for white mold control in North Dakota (15), have systemic activity, their limited mobility through the apoplast (20) is an indication that good canopy penetration is still required to achieve adequate control levels. In this study, high disease pressure resulted in white mold incidence ranging from 44 to $97 \%$ in nonprotected plots, and a mean incidence for fungicide-protected plots of $>29 \%$. It is possible that white mold levels in commercial fields treated with fungicides could be even higher with poorer application coverage or penetration.

The nature of the association between yield loss and plant disease has been studied using simple or multiple regression and correlation analysis and through surfaceresponse associations between yield and disease severity or disease incidence $(3,7,19,21,24,25,30)$. In this study, a negative linear relationship between yield and white mold incidence was detected. Other researchers have found a similar relationship for these variables on soybean (30). For every percent unit increase on white mold incidence, yield of pinto bean (replicated experiments) was reduced by an average of $12 \mathrm{~kg} / \mathrm{ha}$ (range of 7 to 19 $\mathrm{kg} / \mathrm{ha}$ ), while the yield of navy bean (onfarm trials) was reduced an average of 23 $\mathrm{kg} / \mathrm{ha}$ (range of 19 to $26 \mathrm{~kg} / \mathrm{ha}$ ). The coefficients of determination $\left(R^{2}\right)$ were highly significant and, in general, explained more than 50 and $90 \%$ of the variability observed in replicated experiments and onfarm trials, respectively. However, these associations only apply to conditions where high disease pressure prevail. No significant yield differences were detected between fungicide-protected and nonprotected plots when the average disease incidence (Carrington 1998) or disease sever- ity (Carrington 2000) was low. Other researchers have found similar results $(8,27)$. Thus, using the numbers described above to estimate yield losses under low disease pressure could result in overestimation of the damage.

The second-degree polynomial equation that described the association between disease incidence and severity showed sharp increments in disease severity when incidence was higher than 50\%; whereas, at incidences lower than $40 \%$, disease severity readings were under $10 \%$. Kerr et al. (12), working on irrigated dry bean cultivars, determined that the relationship between yield and white mold severity, based on observations of individual plants, also was explained by a second-degree polynomial equation; however, they indicated that disease severity lower than $40 \%$ did not have an impact on yield. In this study, the mean for disease severity in nonprotected and fungicide-protected plots was 34 and $10 \%$, respectively (data not shown), but yields on average were $33 \%$ higher in the latter. It is possible that infected plants compensate better for the impact of the disease when irrigation is provided. Measuring white mold severity is more difficult and subjective than measuring its incidence. The polynomial that described their association in this article accounted for $90 \%$ of the variation observed in the field and is an indication that, under low disease pressure, taking data on disease incidence should be enough to describe an epidemic and its potential impact on yield.

The data suggest that pinto bean tolerated white mold infection better than navy bean. In this study, all pinto cultivars had an indeterminate growth habit type III, whereas the navy bean cultivars had either an indeterminate type II or a determinate type I. The ability of type III bean cultivars

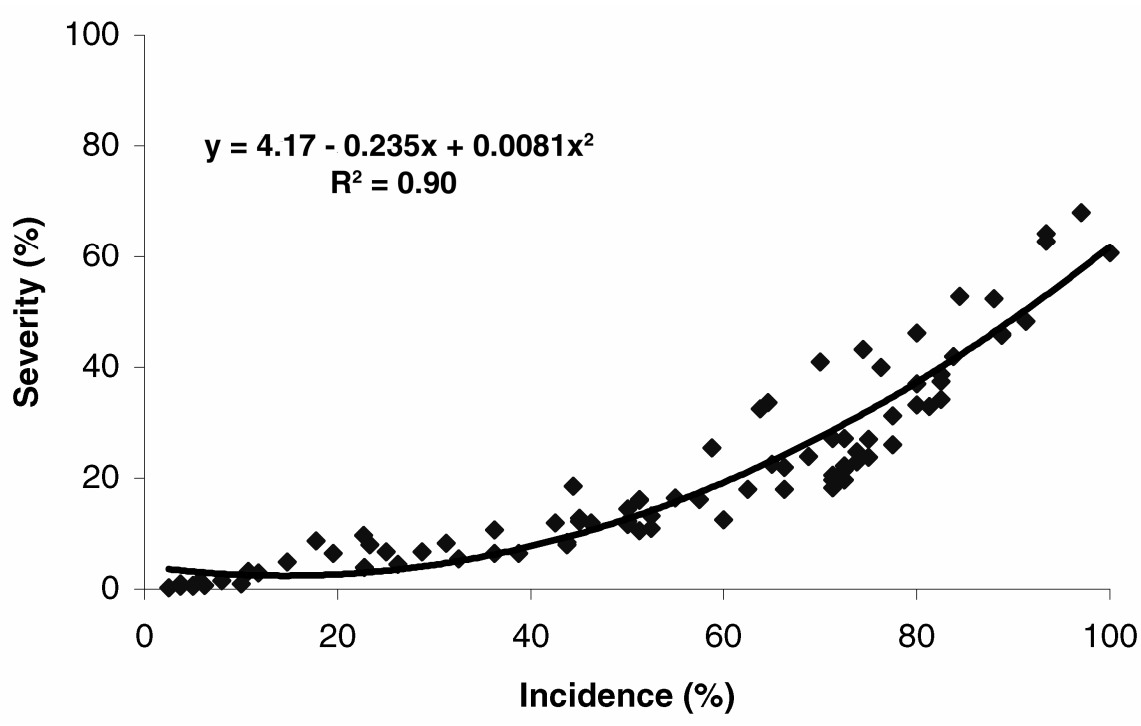

Fig. 2. Relationship between white mold incidence and severity at experiments conducted between 1997 and 2001 in North Dakota. Each data point represents the mean of four replications. The coefficient of determination was significant at $P=0.0001$. to continue producing more lateral branches after the reproductive stage has started may be an indication that they also can compensate better for yield than the more upright type I bushy navy bean, which stop growing once the flowering stage sets in (13). Further, the upright plant architecture found in most of the indeterminate cultivars has not been correlated with increased disease escape (26) under varying production systems and conditions.

Genetic factors aside, the ability of plants to tolerate disease also is related to their nutritional condition as influenced by soil fertility, fertilization practices, and plant population at the sampling site. The foliar application of calcium compounds alone or in combination with reduced fungicide doses in the experiments analyzed in this study did not increase yield significantly when compared with nontreated plots or with plots treated with a similar fungicide dose, respectively (5). Incidence of diseases other than white mold was negligible at all locations and years. The relationship between disease and yield also is affected by the timing of initial infection and by environmental conditions prevalent after the infection process has started (30), locations and years usually are required to reach sound conclusions. In this study, data for navy bean analysis was produced in commercial farms over a period of 3 years in four locations in North Dakota.

The association found in this article between white mold incidence and yield confirms the importance of this disease as a limiting problem for the dry bean industry. The average disease incidence in replicated experiments was 33\%; therefore, we decided to use that value as the cutoff point to extrapolate yield losses. A field survey that scouted over 90 fields in the which explains why data from multiple 
main dry bean-producing areas of North Dakota (10) indicated that $19 \%$ of the fields had an average white mold incidence of $43 \%$. Considering a grower price for dry beans at $\$ 0.34 / \mathrm{kg}$ as published by the USDA-CO Department of Agriculture Market News for 9 March 2004, a simple calculation would place yield losses for 2003 at about $120 \mathrm{~kg} / \mathrm{ha}$ or $\$ 53.04 / \mathrm{ha}$. If the pinto bean acreage harvested in North Dakota in 2003 is similar to that of 2002 $\left(1.86 \times 10^{5} \mathrm{ha}\right)(11)$, yield losses attributed to white mold could have approached $\$ 1.9$ million without considering the cost of the fungicide and its application.

\section{LITERATURE CITED}

1. Abawi, G. S., and Grogan, R. G. 1979. Epidemiology of diseases caused by Sclerotinia species. Phytopathology 69:899-904.

2. Abawi, G. S., Polach, F. J., and Molin, W. T. 1975. Infection of bean by ascospores of Whetzelinia sclerotiorum. Phytopathology 65:673678.

3. Bhathal, J. S., Loughman, R., and Speijers, J. 2003. Yield reduction in wheat in relation to leaf disease from yellow (tan) spot and Septoria nodorum blotch. Eur. J. Plant Pathol. 109: 435-443.

4. Boland, G. J., and Hall, R. 1988. Epidemiology of Sclerotinia stem rot of soybean in Ontario. Phytopathology 78:1241-1245.

5. del Río, L. E., Gross, P. L., and Lamppa, R. S. 2002. Effect of foliar applications of calcium on control of white mold on dry beans. (Abstr.) Phytopathology 92:S18.

6. Ferrell, M. A. 2002. Effect of water $\mathrm{pH}$ on the chemical stability of pesticides. University of Wyoming Pesticide Education Program Fact Sheet MP-February 2002.

7. Fininsa, C. 2003. Relationship between common bacterial blight severity and bean yield loss in pure stand and bean-maize intercropping systems. Intl. J. Pest Manage. 49:177-185.

8. Forster, R. L., and Strausbaugh, C. A. 2001.
Control of white mold of dry beans with foliar sprays in Jerome County, ID, 2000. Fungic. Nematicide Tests 56:FC30.

9. Gossen, B. D., Rimmer, S. R., and Holley, J. D. 2001. First report of resistance to benomyl fungicide in Sclerotinia sclerotiorum. Plant Dis. 85:1206.

10. Harikrishnan, R., del Río, L. E., and Lamppa, R. S. 2004. Prevalence of dry bean diseases in North Dakota-2003. (Abstr.) Phytopathology 94:S39.

11. Hartwig, D., and Meyer, B. 2003. North Dakota Agricultural Statistics 2003. North Dakota Agricultural Statistics Service, Fargo, ND.

12. Kerr, E. D., Steadman, J. R., and Nelson, L. A. 1978. Estimation of white mold disease reduction of yield and yield components of dry edible beans. Crop Sci. 18:275-279.

13. Kolkman, J. M., and Kelly, J. D. 2002. Agronomic traits affecting resistance to white mold in common bean. Crop Sci. 42:693-699.

14. Lamey, H. A. 1997. Water improves spray coverage. Northarvest Bean Grow. 3:10-11.

15. Lamey, H. A., Luecke, J. L., Glogoza, P. A., Zollinger, R. K., Berglund, D. R., and Grafton, K. F. 2000 dry bean grower survey of pest problems and pesticide use in Minnesota and North Dakota. N. D. State Univ. Ext. Rep. No. 72.

16. Lamey, H. A., McMullen, M. P., Venette, J. R., Grafton, K. F., Zollinger, R. K., Luecke, J. L., Berglund, D. R., and Glogoza, P. A. 2000. 1999 dry bean grower survey. N. D. State Univ. Ext. Rep. No. 64.

17. Lamey, H. A., Zollinger, R. K., McMullen, M. P., Luecke, J. L., Venette, J. R., Berglund, D. R., Grafton, K. F., and Glogoza, P. A. 1999. 1998 dry bean grower survey of pest problems and pesticide use in Minnesota and North Dakota. N. D. State Univ. Ext. Rep. No. 58.

18. Lebaron, M. J. 1974. Dry Bean Growth Stages. University of Idaho, Curr. Inf. Ser. 228.

19. LeClerg, E. L. 1971. Field experiments for assessment of crop losses. Pages 2.1/1-2.1.11 in: Crop Loss Assessment Methods. FAO Manual on the Evaluation and Prevention of Losses by Pests, Disease and Weeds. L. Chiarappa, ed. CAB International, Oxford, UK.

20. Lyr, H. 1995. Modern Selective Fungicides:
Properties, Applications, Mechanisms of Action, 2nd ed. Gustav Fischer Verlag, Villengang, Germany, and New York.

21. McKirdy, S. J., Jones, R. A. C., and Nutter, F. W. 2002. Quantification of yield losses caused by Barley yellow dwarf virus in wheat and oats. Plant Dis. 86:769-773.

22. Morton, J. G., and Hall R. 1989. Factors determining the efficacy of chemical control of white mold in white bean. Can. J. Plant Pathol. 11:297-302.

23. Mueller, D. S., Dorrance, A. E., Derksen, R. C., Ozkan, E., Kurle, J. E., Grau, C. R., Gaska, J. M., Hartman, G. L., Bradley, C. A., and Pedersen W. L. 2002. Efficacy of fungicides on Sclerotinia sclerotiorum and their potential for control of Sclerotinia stem rot on soybean. Plant Dis. 86:26-31.

24. Nutter, F. W., Guan, J., Gotlieb, A. R., Rhodes, L. H., Grau, C. R., and Sulc, R. M. 2002. Quantifying alfalfa yield losses caused by foliage diseases in Iowa, Ohio, Wisconsin, and Vermont. Plant Dis. 86:269-277.

25. Romig, R. W., and Calpouzos, L. 1970. The relationship between stem rust and loss in yield of spring wheat. Phytopathology 60:1801-1805.

26. Schwartz, H. F., Casciano, D. H., Asenga, J. A., and Wood, D. R. 1987. Field measurement of white mold effects upon dry beans with genetic resistance or upright plant architecture. Crop Sci. 27:699-702.

27. Strausbaugh, C. A., Forster, R. L., and Koehn, A. C. 2003. Control of white mold of dry beans with foliar sprays in Jerome County, ID, 2002. Fungic. Nematicide Tests 58:FC052.

28. Tu, J. C. 1989. Modes of primary infection caused by Sclerotinia sclerotiorum in navy bean. Microbios 57:85-91.

29. Weiss, A., Kerr, A. E., and Steadman, J. R 1980. Temperature and moisture influences on development of white mold disease (Sclerotinia sclerotiorum) on Great Northern beans. Plant Dis. 64:757-759.

30. Yang, X. B., Lundeen, P., and Uphoff, M. D. 1999. Soybean varietal response and yield loss caused by Sclerotinia sclerotiorum. Plant Dis. 83:456-461. 